Bull. Chem. Soc. Ethiop. 2021, 35(2), 413-424.

(c) 2021 Chemical Society of Ethiopia and The Authors

ISSN 1011-3924

DOI: https://dx.doi.org/10.4314/bcse.v35i2.14

Printed in Ethiopia

Online ISSN 1726-801X

\title{
SOLVENT FREE SYNTHESIS OF HYDRAZINE CARBOTHIOAMIDE DERIVATIVES AS A PRECURSOR IN THE PREPARATION OF NEW MONONUCLEAR Mn(II), Cu(II), AND Zn(II) COMPLEXES: SPECTROSCOPIC CHARACTERIZATIONS
}

\author{
Ghaferah H. Al-Hazmi ${ }^{1}$, Hosam A. Saad ${ }^{2 *}$, Abeer M. Alosaimi ${ }^{2}$ and Moamen S. Refat ${ }^{2}$ \\ ${ }^{1}$ Department of Chemistry, College of Science, Princess Nourah bint Abdulrahman University, \\ Riyadh 11671, Saudi Arabia \\ ${ }^{2}$ Department of Chemistry, College of Science, Taif University, P.O. Box 11099, Taif 21944 ,
} Saudi Arabia

(Received February 28, 2021; Revised July 25, 2021; Accepted August 25, 2021)

\begin{abstract}
Over the last few years considerable attention has been devoted to the study of Schiff base complexes of metal(II) containing nitrogen, oxygen and sulfur donor ligands due to their diverse biological activities. Therefore, the Schiff base thiosemicarbazone derivatives of 2-(2-hydroxy-3-methoxybenzylidene) hydrazine carbothioamide $\left(\mathrm{HL}_{1}\right)$ and 2-(4-bromo-2-hydroxy-3-methoxybenzylidene) hydrazine carbothioamide $\left(\mathrm{HL}_{2}\right)$ were synthesized with solvent free technique using silica gel as material support for the reaction. The structures of the precursor's organic products confirmed with their ${ }^{1} \mathrm{H},{ }^{13} \mathrm{C}$ NMR, IR and microanalysis data. Six new manganese(II), copper(II), and zinc(II) complexes of $\mathrm{HL}_{1}$ and $\mathrm{HL}_{2}$ 2-(2-hydroxy-3-methoxybenzylidene) hydrazinecarbothioamide derivatives with the general formulation $\left[\mathrm{ML}_{1} \mathrm{Cl}\right]$ and $\left[\mathrm{ML}_{2} \mathrm{Cl}\right]$, where $\mathrm{M}=\mathrm{Mn}^{2+}, \mathrm{Cu}^{2+}$, and $\mathrm{Zn}^{2+}$ were prepared and well discussed by using elemental analyses, magnetic moments, molar conductance, infrared and electronic spectral techniques. The assignments data of spectroscopic analysis confirm that the synthesized thiosemicarbazone Schiff bases of acts as a tridentate ligand as sulfur-oxygen-nitrogen donating atoms. The values of magnetic moments agreed with the data of electronic spectra which both suggested a fourcoordination geometry of the synthesized complexes.
\end{abstract}

KEY WORDS: Schiff base, Thiosemicarbazone, Manganese(II) complex, Copper(II) complex, Zinc(II) complex

\section{INTRODUCTION}

The use of cisplatin in treatment over the past 50 years $[1,2]$ demonstrates that mineral complexes can have significant antitumor activity, particularly the copper compounds that attract attention as an example of cancer, complexes, where the copper ion concentration in the tumor cells is higher than that in the healthy cells [3-5]. Salicylaldehyde thiosemicarbazone ligand complex with copper have showed good resistant, in vitro, against colon carcinoma, melanoma, pancreatic adenocarcinoma, thyroid carcinoma, and ovarian carcinoma [6]. Some benzaldehyde thiosemicarbazone derivatives demonstrate antimycobacterial activity, under hypoxia, against M. tuberculosis [7]. Palladium (II) salicylaldiminato thiosemicarbazone complexes showed an amazing antiprotozoal activity on metronidazole resistant Trichomonas vaginalis [8]. The organometallic complexes of osmium(II) and ruthenium(II) thiosemicarbazone derivatives have an antiproliferative efficiency [9]. In literature, the synthesized palladium(II) 3-methoxysalicylaldehyde thiosemicarbazone complexes gave a biological potential with calf thymus DNA, bovine serum albumin, and also in vitro the complexes showed a cytotoxicity towards human breast cancer cells (MCF-7) [10]. The chemistry of Schiff base transition metal complexes has become highly attractive due to their wide pharmacokinetic profile providing a variety of compounds with different activities [11-15]. In recent years, the distinguish ligands containing sulfur atom such as thiosemicarbazones derivatives and their complexes with some of transition metal ions have a great attention in the

*Corresponding author. E-mail: h.saad@tu.edu.sa

This work is licensed under the Creative Commons Attribution 4.0 International License 
field of medicinal chemistry according to their therapeutic importance, such as anti-bacterial, anti-fungal, anti-viral, anti-allergic, anti-tumor, anticancer, and anti-HIV activities [16-28]. Based on these vital items, herein we reported the synthesis and spectroscopic characterization of two new Schiff base complexes of 2-(2-hydroxy-3-methoxybenzylidene) hydrazinecarbothioamide derivatives ligands with manganese(II), copper(II), and zinc(II) metal ions.

\section{EXPERIMENTAL}

\section{Reagents and chemicals}

The chemical used in this study were of fine grade chemical. The manganese(II), copper(II), and zinc(II) metal salts were used as a chloride. The solvents (methanol, diethyl ether, and dimethyl sulfoxide) were used without further purification.

\section{Instrumentations}

Microanalytical analysis $(\% \mathrm{C}, \mathrm{H}$ and $\mathrm{N})$ were performed using a Perkin Elmer CHN 2400 (USA). With $10^{-3} \mathrm{M}$ concentration the molar conductivities using dimethyl sulfoxide solvent were detected by Jenway 4010 conductivity meter. Electronic UV-Vis absorption spectra within 800-200 nm range were scanned in DMSO solvent using a UV2-Unicam UV/Vis Spectrophotometer fitted with a quartz cell of $1.0 \mathrm{~cm}$ path length. Infrared using discs of potassium bromide $\left(4000-400 \mathrm{~cm}^{-1}\right)$ were recorded on Perkin-Elmer 1650 spectrometer. ${ }^{1} \mathrm{H}-$ NMR and ${ }^{13} \mathrm{C}$-NMR spectra were determined using solutions of dimethyl sulfoxide on a Bruker AC-400 Hz instrument using an internal standard tetramethylsilane. The $\mathrm{X}_{\mathrm{g}}$ mass susceptibility of complexity was determined using a Gouy magnetic balance at room temperature. The purity of organic ligand was analyzed using Shimadzu GC-MS-QP 1000 EX spectrometer. Melting points were estimated by Electrothermal IA 9100 series digital apparatus. The metal ion contents were calculated using gravimetrically method.

Synthesis of thiosemicarbazones $\mathbf{2} \boldsymbol{a}-\boldsymbol{b}$ (general procedures)

Method A (traditional method). The appropriate 3-methoxysalicylaldehyde derivative ( $0.01 \mathrm{~mol})$ dissolved in $15 \mathrm{~mL}$ absolute ethanol, then thiosemicarbazide $(0.091 \mathrm{~g}, 0.01 \mathrm{~mol})$ was added to the hot stirred solution of salicylaldehyde. The reflux of the reaction mixture stopped after $6 \mathrm{hr}$ (the reaction monitored with TLC, $\left(\mathrm{CH}_{2} \mathrm{Cl}_{2} / \mathrm{MeOH}\right.$ 9:1 mixture), $\left.\mathrm{R}_{\mathrm{f}}=056\right)$. After solvent evaporation, the solid product formed washed with little amount of water then after drying crystallized with ethanol, yield: $75-81 \%$, m.p.: $220-222{ }^{\circ} \mathrm{C}$ and $250-252{ }^{\circ} \mathrm{C}$.

Method B (solvent free method). Compound 1a,b $(0.01 \mathrm{~mol})$ and thiosemicarbazide $(0.091 \mathrm{~g}$, $0.01 \mathrm{~mol}$ ) were mixed in a dry glass beaker and then added 0.5 g silica gel (200-400 mesh), methylene chloride $15 \mathrm{~mL}$ added and the mixture stirred with glass rod until the $\mathrm{CH}_{2} \mathrm{Cl}_{2}$ evaporates on cold, the dry mixture irradiated for 2.0-3.0 min in a domestic microwave oven $(2450 \mathrm{MHz}, 800 \mathrm{~W})$. After irradiation finished, the content dissolved in acetone and filtered off. The product formed after acetone evaporation crystallized from ethanol, yield: 82-89\%, m.p.: 223-225 ${ }^{\circ} \mathrm{C}$ and $251-253{ }^{\circ} \mathrm{C}$. The synthesis route of the Schiff base thiosemicarbazone derivatives of 2-(2-hydroxy-3-methoxybenzylidene) hydrazine carbothioamide $\left(\mathrm{HL}_{1}\right)$ and 2-(4bromo-2-hydroxy-3-methoxybenzylidene) hydrazine carbothioamide $\left(\mathrm{HL}_{2}\right)$ is shown in Scheme 1. 
<smiles>[X]c1ccc(C=O)c(O)c1OC</smiles>

1a, $\mathrm{X}=\mathrm{H}$

$1 \mathrm{~b}, \mathrm{X}=\mathrm{Br}$<smiles>NNC(N)=S</smiles><smiles>CC[SiH3]</smiles><smiles>[X]c1ccc(/C=N/NC(N)=S)c(O)c1OC</smiles>

2a, $X=H$

2b, $X=B r$

Scheme 1. Synthesis of 2-(2-hydroxy-3-methoxybenzylidine) hydrazine carbothioamide derivatives.

Preparation procedure of Schiff base metal complexes

A $25 \mathrm{~mL}$ of methanolic solution from $\left(\mathrm{HL}_{1}, 0.226 \mathrm{~g}, 1 \mathrm{mmol} / \mathrm{HL}_{2}, 0.305 \mathrm{~g}, 1 \mathrm{mmol}\right)$ was taken in a six necked round bottom flask and kept on magnetic stirring. A warm methanolic solution $(25 \mathrm{~mL})$ of $\mathrm{MnCl}_{2}(0.126 \mathrm{~g}, 1 \mathrm{mmol}), \mathrm{CuCl}_{2}(0.135 \mathrm{~g}, 1 \mathrm{mmol})$, and $\mathrm{ZnCl}_{2}(0.137 \mathrm{~g}, 1 \mathrm{mmol})$ was added drop wise and stirred with heating for $3 \mathrm{~h}$. On cooling, precipitates were formed which were filtered, washed with methanol, and diethyl ether and dried in vacuum desiccators over anhydrous $\mathrm{CaCl}_{2}$. The complexes were soluble in DMSO and DMF. The complexes have the general formula $\left[\mathrm{ML}_{1} \mathrm{Cl}\right]$ and $\left[\mathrm{ML}_{2} \mathrm{Cl}\right]$, where $\mathrm{M}=\mathrm{Mn}^{2+}, \mathrm{Cu}^{2+}$, and $\mathrm{Zn}^{2+}$. The synthesis pathway of complexes is shown in Scheme 2.

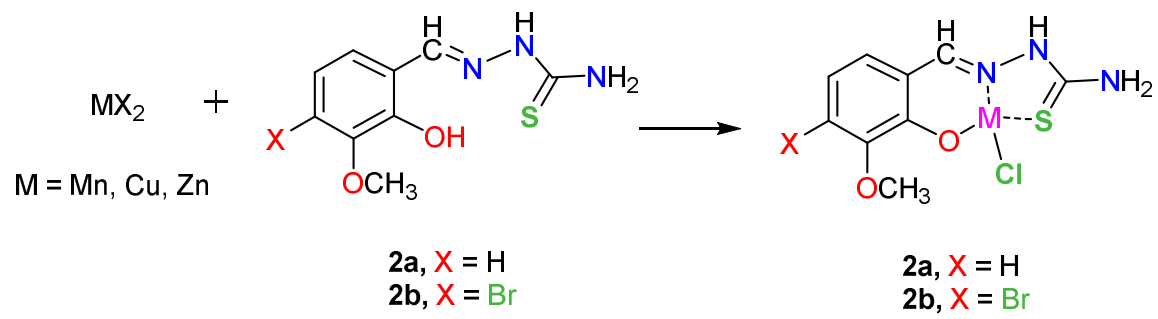

Scheme 2. Synthesis route of [ML1Cl] and ML2Cl].

\section{RESULTS AND DISCUSSION}

\section{Ligand characterization}

Salicylaldehyde derivatives thiosemicarbazone ligands prepared for the first time using solvent free technique. The reaction between thiosemicarbazide and salicylaldehyde derivatives carried out under microwave irradiation over silica gel for 2-3 $\mathrm{min}$. in domestic microwave oven (2450 $\mathrm{MHz}, 800 \mathrm{~W})$. The structures of the resulted products, 2-(2-hydroxy-3-methoxybenzylidene) hydrazinecarbothioamide and 2-(4-bromo-2-hydroxy-3-methoxybenzylidene) hydrazinecarbothio amide $\mathbf{2 a}, \mathbf{b}$ were confirmed with their spectral data (Figure 1). The ${ }^{1} \mathrm{H}$ NMR of compounds 2a and $\mathbf{2 b}$ showed two singlets for the two unsymmetrically protons $\mathrm{NH}_{2}$ group, where the difference in electronic environment of the two protons resulted from the presence of the thiocarbonyl group closer to one than another. The ${ }^{1} \mathrm{H}$ NMR of compound $\mathbf{2} \mathbf{b}$ showed two doublets for the two aromatic protons while in 2a showed beside the two doublets a multiplet signal for the $C_{5}$ in benzene ring. 
2-(2-Hydroxy-3-methoxybenzylidene)hydrazinecarbothioamide $2 \boldsymbol{a}\left(H L_{1}\right)$. IR, v; $3448 \mathrm{~cm}^{-1}(\mathrm{OH})$, $3351,3330 \mathrm{~cm}^{-1}\left(\mathrm{NH}_{2}\right), 3271 \mathrm{~cm}^{-1}(\mathrm{NH}), 1610(\mathrm{C}=\mathrm{N}), 1235(\mathrm{C}=\mathrm{S}) ;{ }^{1} \mathrm{H}$ NMR $\left(\mathrm{DMSO}-d_{6}, 300\right.$ $\mathrm{MHz}): \delta=3.72\left(\mathrm{~s}, 3 \mathrm{H}, \mathrm{OCH}_{3}\right), 6.35(\mathrm{~s}, 1 \mathrm{H}, \mathrm{CH}=\mathrm{N}), 6.38,6.39\left(2 \mathrm{~s}, 2 \mathrm{H}, \mathrm{NH}_{2}\right), 7.10(\mathrm{~d}, 1 \mathrm{H}, J=$ $4.4 \mathrm{~Hz}$, aromatic $\left.\mathrm{C}_{6} H\right), 7.18\left(\mathrm{dd}, 1 \mathrm{H}\right.$, aromatic $\left.\mathrm{C}_{5} H\right), 7.24\left(\mathrm{~d}, 1 \mathrm{H}, 4.4 \mathrm{~Hz}\right.$, aromatic $\left.\mathrm{C}_{4} H\right), 9.75$ $(\mathrm{s}, 1 \mathrm{H}, \mathrm{OH}), 11.12(\mathrm{~s}, 1 \mathrm{H}, \mathrm{NH}) \cdot{ }^{13} \mathrm{C} \mathrm{NMR}\left(\mathrm{DMSO}-d_{6}, 100 \mathrm{MHz}\right): \delta=63.10\left(\mathrm{OCH}_{3}\right), 117.7$ (C1), 123.3 (C4), 125.3 (C5), $131.5(\mathrm{C} 6), 151.2\left(C-\mathrm{OCH}_{3}\right), 153.2(\mathrm{C}-\mathrm{OH}), 171.6(\mathrm{C}=\mathrm{S})$. Calcd for $\mathrm{C}_{9} \mathrm{H}_{11} \mathrm{~N}_{3} \mathrm{O}_{2} \mathrm{~S}$ (225.27): C, 47.99; $\mathrm{H}, 4.92 ; \mathrm{N}, 18.65 ; \mathrm{S}, 14.23$; found: $\mathrm{C}, 48.07 ; \mathrm{H}, 4.88 ; \mathrm{N}$, $18.31 ; \mathrm{S}, 14.09$.

2-(4-Bromo-2-hydroxy-3-methoxybenzylidene)hydrazinecarbothioamide $2 \boldsymbol{b}\left(H L_{2}\right)$. IR, v; 3452 $\mathrm{cm}^{-1}(\mathrm{OH}), 3355,3325 \mathrm{~cm}^{-1}\left(\mathrm{NH}_{2}\right), 3259 \mathrm{~cm}^{-1}(\mathrm{NH}), 1616(\mathrm{C}=\mathrm{N}), 1249(\mathrm{C}=\mathrm{S}) ;{ }^{1} \mathrm{H}$ NMR (DMSO- $\left.d_{6}, 400 \mathrm{MHz}\right): \delta=3.78\left(\mathrm{~s}, 3 \mathrm{H}, \mathrm{OCH}_{3}\right), 6.33(\mathrm{~s}, 1 \mathrm{H}, \mathrm{CH}=\mathrm{N}), 6.35,6.36\left(2 \mathrm{~s}, 2 \mathrm{H}, \mathrm{NH}_{2}\right)$, $7.06\left(\mathrm{~d}, 2 \mathrm{H}, J=4.4 \mathrm{~Hz}\right.$, aromatic $\left.\mathrm{C}_{6} H\right), 7.15\left(\mathrm{~d}, 2 \mathrm{H}, J=4.0 \mathrm{~Hz}\right.$, aromatic $\left.\mathrm{C}_{5} H\right), 9.83(\mathrm{~s}, 1 \mathrm{H}$, $\mathrm{OH}), 11.01(\mathrm{~s}, 1 \mathrm{H}, \mathrm{NH}) .{ }^{13} \mathrm{C} \mathrm{NMR}\left(\mathrm{DMSO}-d_{6}, 100 \mathrm{Mz}\right): \delta=61.15\left(\mathrm{OCH}_{3}\right), 117.3(\mathrm{C} 1), 119.5$ $(\mathrm{C}-\mathrm{Br}), 124.1$ (C5), $130.7(\mathrm{C} 6), 149.9\left(\underline{C}-\mathrm{OCH}_{3}\right), 151.4(\underline{C}-\mathrm{OH}), 170.7(\mathrm{C}=\mathrm{S})$. Calcd for $\mathrm{C}_{9} \mathrm{H}_{10} \mathrm{BrN}_{3} \mathrm{O}_{2} \mathrm{~S}$ (304.16): C, 35.54; H, 3.31; Br, 26.27; N, 13.81; S, 10.54; found: $\mathrm{C}, 35.32 ; \mathrm{H}$, $3.25 ; \mathrm{Br}, 26.11 ; \mathrm{N}, 13.59 ; \mathrm{S}, 10.44$.

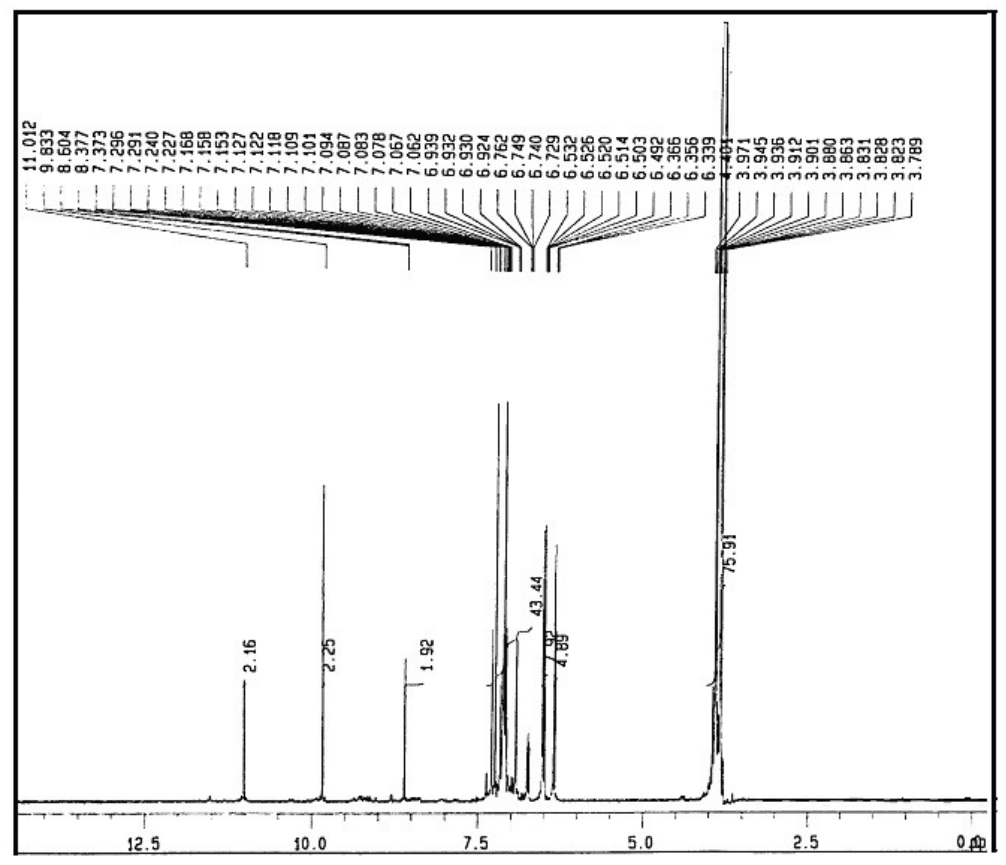



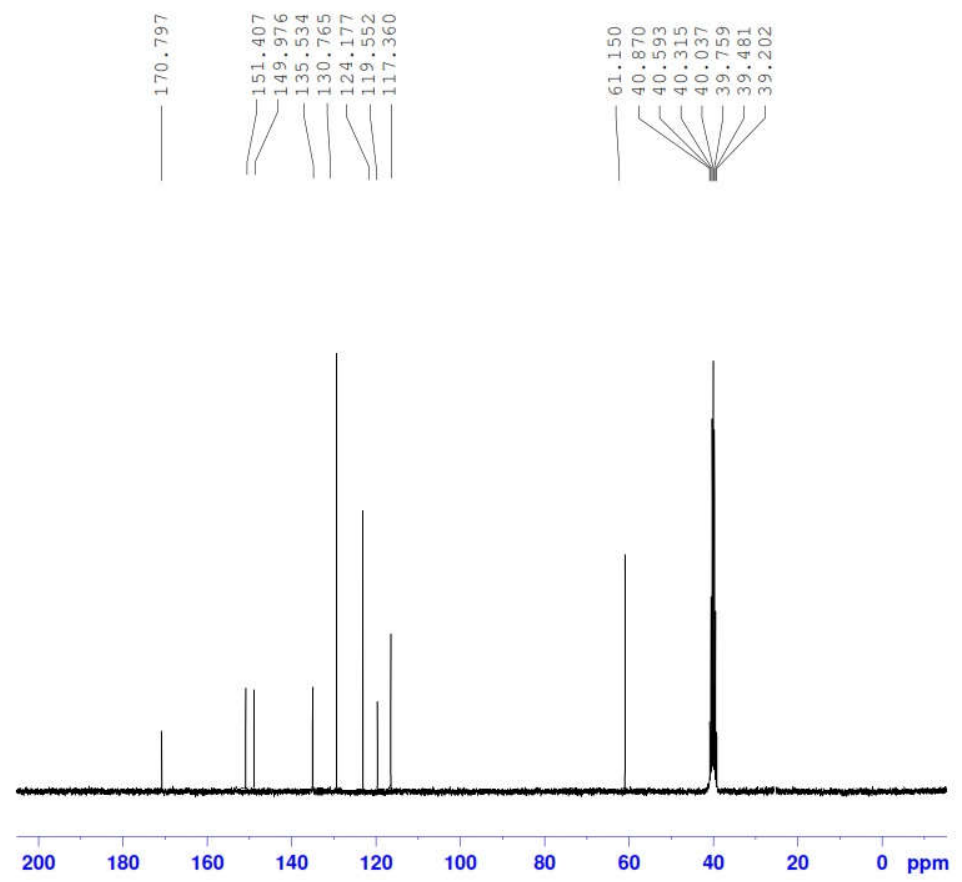

Figure 1. ${ }^{1} \mathrm{H}$ NMR and ${ }^{13} \mathrm{C}$ NMR spectra of compound 2a.

\section{Electronic and magnetic properties}

The manganese(II), copper(II) and zinc(II) complexes display an intense charge transfer (CT) band in the range 217-266 nm, which can be attributed to the $\pi \rightarrow \pi^{*}$ transition of the coordinated Schiff bases $\mathrm{HL}_{1}$ and $\mathrm{HL}_{2}$. The band around 318 and $372 \mathrm{~nm}$ in all the complexes is attributed to the $\mathrm{OH}$ phenolic, $\mathrm{NH}_{2}$, imine $(-\mathrm{HC}=\mathrm{N}-)$ and $\mathrm{C}=\mathrm{S}$ groups. The $\mathrm{Cu}(\mathrm{II})$ complexes show three transition bands at $13513-13423 \mathrm{~cm}^{-1}, 24752-25316 \mathrm{~cm}^{-1}$ and $37735-37736 \mathrm{~cm}^{-1}$ due to the electronic transition bands ${ }^{2} \mathrm{~B}_{1 \mathrm{~g}} \rightarrow{ }^{2} \mathrm{~A}_{1 \mathrm{~g}}$ and two intra ligand charge transfer bands. These electronic transitions and observed magnetic moment value (1.80-1.83 B.M.) suggests squareplanar geometry around $\mathrm{Cu}(\mathrm{II})[30,31]$. The electronic spectra of the $\mathrm{Mn}$ (II) complexes display three absorption bands at $13459 \mathrm{~cm}^{-1}, 26882 \mathrm{~cm}^{-1}$ and $31446 \mathrm{~cm}^{-1}$, due to ${ }^{6} \mathrm{~A}_{1 \mathrm{~g}} \rightarrow{ }^{4} \mathrm{~T}_{1 \mathrm{~g}},{ }^{6} \mathrm{~A}_{1 \mathrm{~g}} \rightarrow{ }^{4} \mathrm{~T}_{2 \mathrm{~g}}(\mathrm{G})$ and ${ }^{6} \mathrm{~A}_{1 \mathrm{~g}} \rightarrow{ }^{4} \mathrm{~T}_{2 \mathrm{~g}}(\mathrm{D})$ transitions, respectively [32]. The manganese(II) complexes gave 5.85-5.91 B.M. values, indicating a high spin complex and suggesting tetrahedral geometry [33, 34]. In the case of $\mathrm{Zn}(\mathrm{II})$ complexes, no significant absorption bands in their electronic spectra were obtained due to diamagnetic nature of zinc metal ion. 
Table 1. Characterization of manganese(II), copper(II) and zinc(II) complexes.

\begin{tabular}{|c|c|c|c|c|c|c|c|c|}
\hline \multirow[t]{2}{*}{ Complexes } & \multirow[t]{2}{*}{ Color } & \multicolumn{5}{|c|}{ Elemental analysis, found (calcd.) } & \multirow{2}{*}{$\begin{array}{c}\Lambda_{\mathrm{m}} \\
\Omega^{-1} \cdot \mathrm{cm}^{2} \cdot \mathrm{mol}^{-1}\end{array}$} & \multirow[t]{2}{*}{$\mu_{\text {eff }}$ (B.M.) } \\
\hline & & $\mathrm{C} \%$ & $\mathrm{H} \%$ & $\mathrm{~N} \%$ & $\mathrm{~S} \%$ & $\mathrm{M} \%$ & & \\
\hline $\mathrm{H} \mathrm{L}_{1}$ & Yellow & $\begin{array}{l}48.07 \\
(47.99)\end{array}$ & $\begin{array}{l}4.88 \\
(4.92)\end{array}$ & $\begin{array}{l}18.31 \\
(18.65)\end{array}$ & $\begin{array}{l}14.09 \\
(14.23)\end{array}$ & - & 7 & - \\
\hline $\mathrm{H} \mathrm{L}_{2}$ & Orange & $\begin{array}{l}35.32 \\
(35.54)\end{array}$ & $\begin{array}{l}3.25 \\
(3.31)\end{array}$ & $\begin{array}{l}13.59 \\
(13.81)\end{array}$ & $\begin{array}{l}10.44 \\
(10.54)\end{array}$ & - & 9 & - \\
\hline$\left[\mathrm{MnL}_{1} \mathrm{Cl}\right]$ & Yellow & $\begin{array}{l}34.21 \\
(34.36)\end{array}$ & $\begin{array}{l}3.12 \\
(3.20)\end{array}$ & $\begin{array}{l}13.34 \\
(13.36)\end{array}$ & $\begin{array}{l}10.15 \\
(10.19)\end{array}$ & $\begin{array}{l}17.11 \\
(17.46)\end{array}$ & 20 & 5.85 \\
\hline$\left[\mathrm{CuL}_{1} \mathrm{Cl}\right]$ & Green & $\begin{array}{l}33.21 \\
(33.44)\end{array}$ & $\begin{array}{l}3.10 \\
(3.12)\end{array}$ & $\begin{array}{l}12.89 \\
(13.00)\end{array}$ & $\begin{array}{l}9.89 \\
(9.92)\end{array}$ & $\begin{array}{l}19.43 \\
(19.66)\end{array}$ & 15 & 1.83 \\
\hline$\left[\mathrm{ZnL}_{1} \mathrm{Cl}\right]$ & Yellow & $\begin{array}{l}33.09 \\
(33.25)\end{array}$ & $\begin{array}{l}3.08 \\
(3.10)\end{array}$ & $\begin{array}{l}12.90 \\
(12.93)\end{array}$ & $\begin{array}{l}9.82 \\
(9.86)\end{array}$ & $\begin{array}{l}20.05 \\
(20.11)\end{array}$ & 18 & Diamagnetic \\
\hline$\left[\mathrm{MnL}_{2} \mathrm{Cl}\right]$ & Brown & $\begin{array}{l}27.40 \\
(27.47)\end{array}$ & $\begin{array}{l}2.28 \\
(2.31)\end{array}$ & $\begin{array}{l}10.65 \\
(10.68)\end{array}$ & $\begin{array}{l}8.14 \\
(8.15)\end{array}$ & $\begin{array}{l}13.90 \\
(13.96)\end{array}$ & 14 & 5.91 \\
\hline$\left[\mathrm{CuL}_{2} \mathrm{Cl}\right]$ & Green & $\begin{array}{l}26.75 \\
(26.88)\end{array}$ & $\begin{array}{l}2.24 \\
(2.26)\end{array}$ & $\begin{array}{l}10.43 \\
(10.45)\end{array}$ & $\begin{array}{l}7.95 \\
(7.97)\end{array}$ & $\begin{array}{l}15.77 \\
(15.80)\end{array}$ & 12 & 1.80 \\
\hline$\left[\mathrm{ZnL}_{2} \mathrm{Cl}\right]$ & Yellow & $\begin{array}{l}26.60 \\
(26.76)\end{array}$ & $\begin{array}{l}.24 \\
(2.25)\end{array}$ & $\begin{array}{l}10.38 \\
(10.40)\end{array}$ & $\begin{array}{l}7.91 \\
(7.94)\end{array}$ & $\begin{array}{l}16.09 \\
(16.18)\end{array}$ & 17 & Diamagnetic \\
\hline
\end{tabular}

\section{Infrared spectroscopy}

Infrared spectra of the complexes are shown in Figure 2. The FTIR data of ligands $\mathrm{HL}_{1}$ and $\mathrm{HL}_{2}$, and its metal complexes are listed in Table 2. In general, the $\mathrm{HL}_{1}$ and $\mathrm{HL}_{2}$ both ligands can exhibit thione $\leftrightarrow$ thiol tautomerism since it contains a thioamide $-\mathrm{NH}-\mathrm{C}=\mathrm{S}$ characteristic group. The $v(\mathrm{~S}-\mathrm{H})$ band at $2560 \mathrm{~cm}^{-1}$ is absent in the FTIR spectra of the two ligands, but $v(\mathrm{~N}-\mathrm{H})$ band at $3259-3271 \mathrm{~cm}^{-1}$ is present, indicating that in the solid state two ligands remain as the thione form. The frequency of $v(\mathrm{C}=\mathrm{N})$ band of the thiosemicarbazone moiety appeared at 1610-1616 $\mathrm{cm}^{-1}$ is shifted towards lower or higher wavenumbers in the synthetic complexes indicating coordination via the azomethine nitrogen. This is also confirmed by the appearance of band in complexes in the range of $412-514 \mathrm{~cm}^{-1}$, which has been assigned to the $v(\mathrm{M}-\mathrm{N})$ [35]. A medium to weak band presence at around $\sim 1000 \mathrm{~cm}^{-1}$ is due to the $v(\mathrm{~N}-\mathrm{N})$ group of the thiosemicarbazone moiety. The frequency of this band is shifted towards higher wave number in the spectra of complexes. It is due to the increase in the bond strength, which again confirms the coordination via the azomethine nitrogen. The band appearing at $\sim 1235-1249$ and $820-830 \mathrm{~cm}^{-1}$ corresponding to $v(\mathrm{C}=\mathrm{S})$ in the FTIR spectra of two ligands are shifted towards lower wavenumbers. It indicates that thione sulfur coordinates to the metal ion [36]. During complexation, the band $3448-3452 \mathrm{~cm}^{-1}$ for $v(\mathrm{O}-\mathrm{H})$ is absent evident that oxygen of deprotonated phenolic group was coordinated to metal atoms. In addition, the shifted of $v(\mathrm{C}-\mathrm{O})$ phenolic group to lower wavenumbers also indicated the coordination to the metal ion. Thus, it may be concluded that both ligands behave as tridentate chelating agent coordinating through azomethine nitrogen, phenolic oxygen and thione sulfur. The $\mathrm{C}-\mathrm{H}$ aromatic stretching and bending vibrations appear at $2900-2800 \mathrm{~cm}^{-1}$ and $1450-1400 \mathrm{~cm}^{-1}$, respectively 

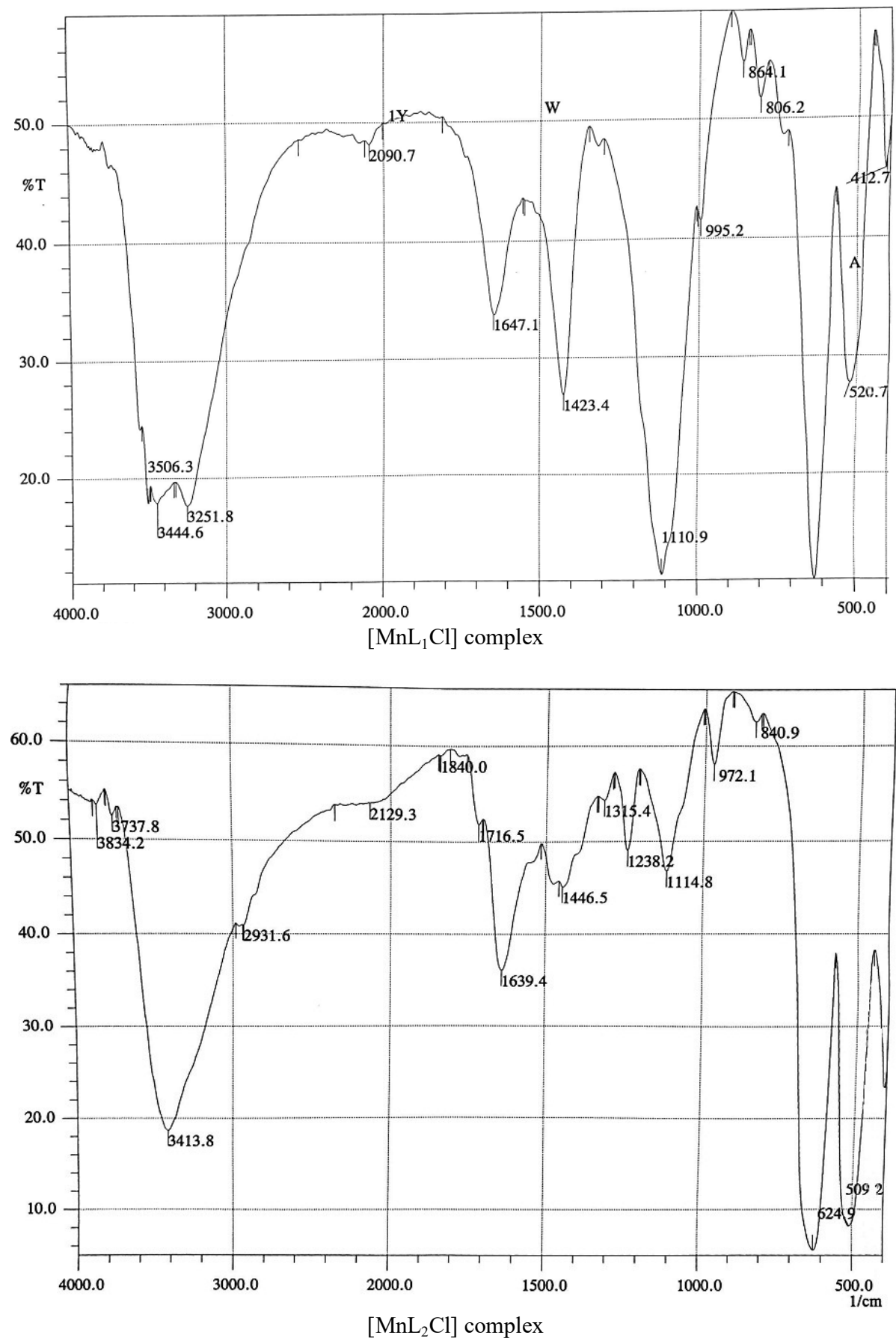

Bull. Chem. Soc. Ethiop. 2021, 35(2) 

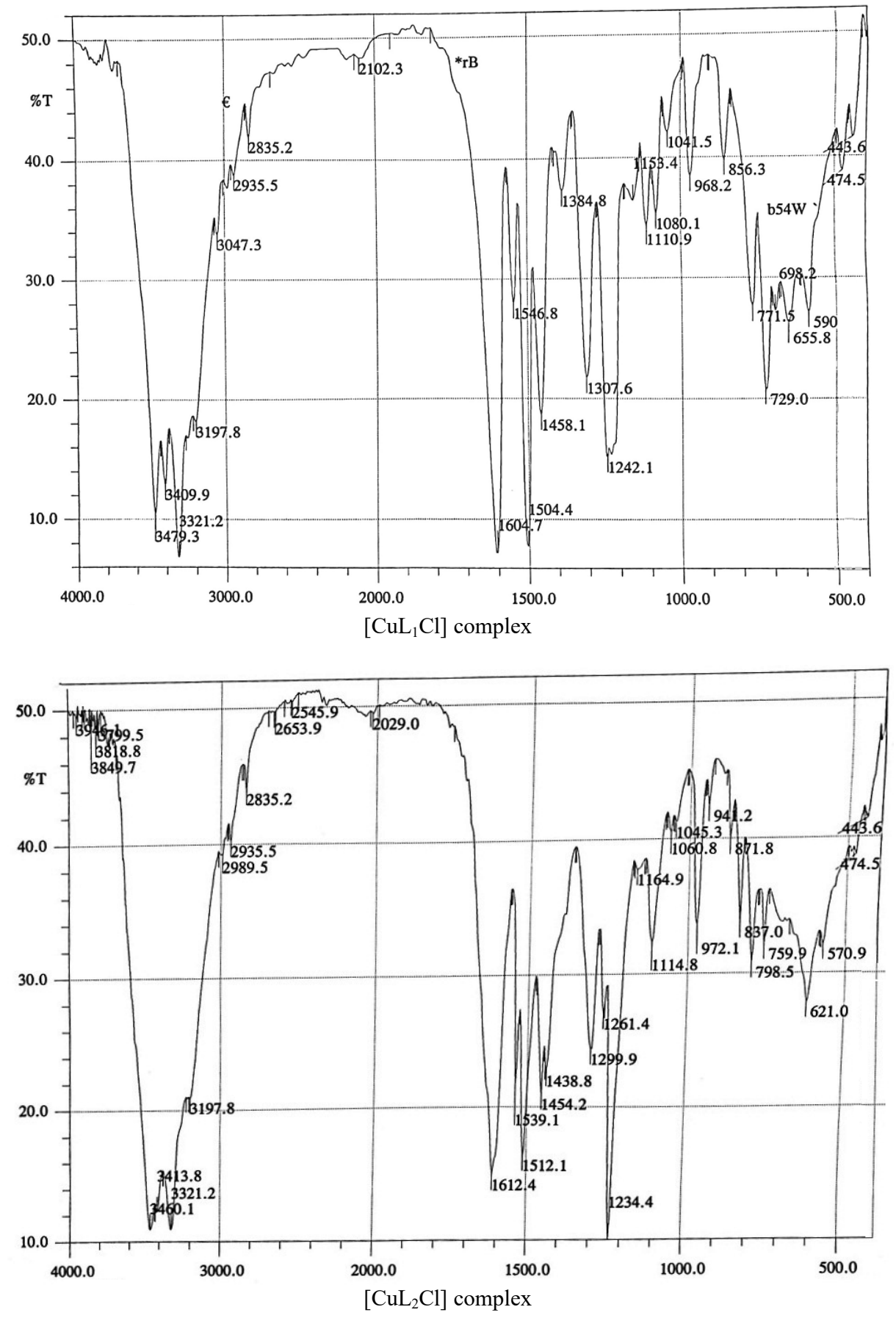

Bull. Chem. Soc. Ethiop. 2021, 35(2) 


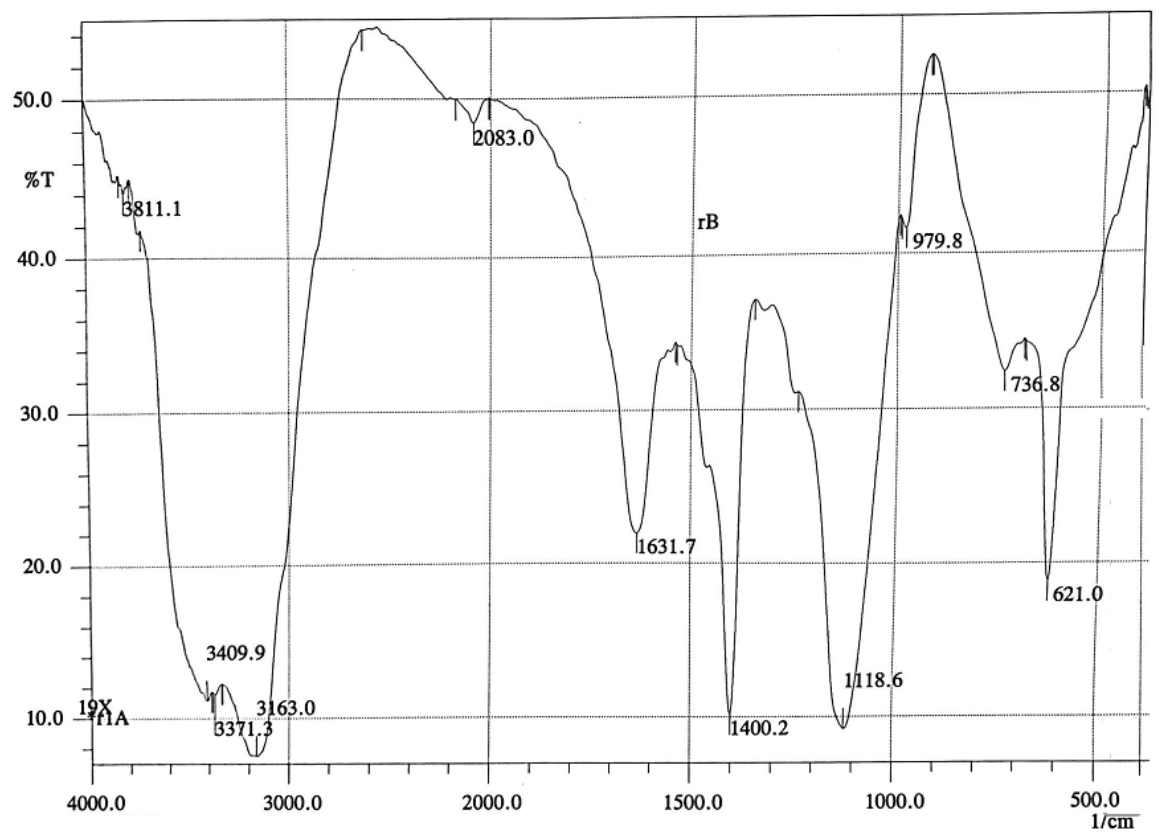

$\left[\mathrm{ZnL}_{1} \mathrm{Cl}\right]$ complex

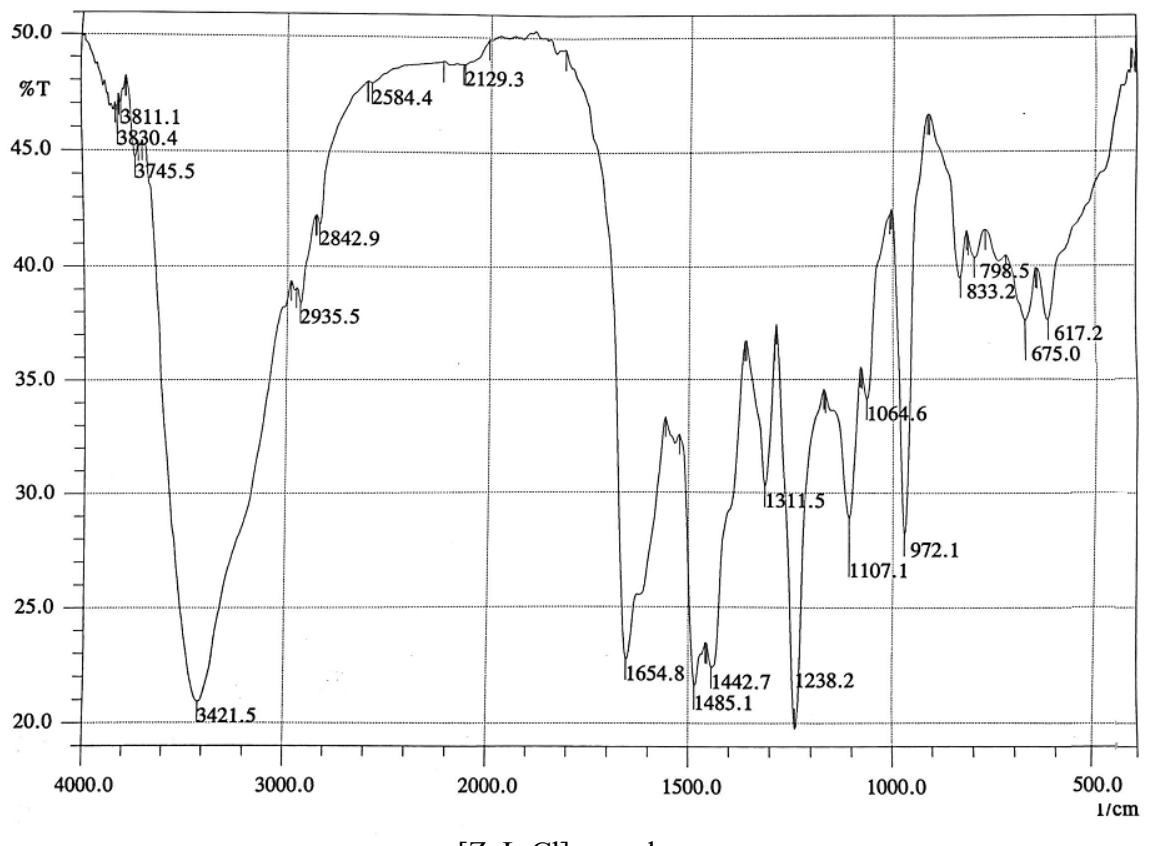

$\left[\mathrm{ZnL}_{2} \mathrm{Cl}\right]$ complex

Figure 2. FTIR spectra of $\mathrm{Mn}(\mathrm{II}), \mathrm{Cu}(\mathrm{II})$, and $\mathrm{Zn}(\mathrm{II})$ complexes.

Bull. Chem. Soc. Ethiop. 2021, 35(2) 
Table 2. Infrared spectral assignments of $\mathrm{HL}_{1}, \mathrm{HL}_{2}, \mathrm{Mn}(\mathrm{II}), \mathrm{Cu}(\mathrm{II})$, and $\mathrm{Zn}$ (II) complexes.

\begin{tabular}{|l|l|l|l|l|l|l|l|l|}
\hline \multirow{2}{*}{ Assignments } & \multicolumn{9}{|c|}{ Compounds } \\
\cline { 2 - 10 } & $\mathrm{HL}_{1}$ & \multicolumn{1}{|c|}{$\mathrm{HL}_{2}$} & \multicolumn{1}{|c|}{ MnL1Cl } & MnL2Cl & CuL1Cl & CuL2Cl & ZnL1Cl & ZnL2Cl \\
\hline$v(\mathrm{OH})$ & 3448 & 3452 & - & - & - & - & - & - \\
\hline$v\left(\mathrm{NH}_{2}\right)$ & 3351 & 3355 & 3445 & 3414 & 3409 & 3460 & 3409 & 3421 \\
& 3330 & 3325 & & & & & & \\
\hline$v(\mathrm{NH})$ & 3271 & 3259 & 3252 & 3250 & 3321 & 3321 & 3371 & 3350 \\
\hline$v(\mathrm{C}=\mathrm{N})$ azomethine & 1610 & 1616 & 1647 & 1639 & 1605 & 1539 & 1631 & 1655 \\
\hline$v(\mathrm{C}=\mathrm{S})$ & 1235 & 1249 & - & - & - & 1234 & - & 1238 \\
& 820 & 830 & 806 & - & 771 & 798 & 737 & 798 \\
\hline$v(\mathrm{C}-\mathrm{O})$ phenolic & 1211 & 1225 & 1110 & 1115 & 1111 & 1115 & 1118 & 1107 \\
& 1056 & 1060 & 995 & 972 & 1041 & 972 & 979 & 972 \\
\hline$v(\mathrm{M}-\mathrm{O})$ & - & - & 521 & 624 & 590 & 570 & 621 & 617 \\
\hline$v(\mathrm{M}-\mathrm{N})$ & - & - & 412 & 509 & 474 & 474 & 510 & 514 \\
\hline
\end{tabular}

\section{CONCLUSION}

Six new $\mathrm{Mn}(\mathrm{II}), \mathrm{Cu}(\mathrm{II})$, and $\mathrm{Zn}(\mathrm{II})$ complexes have been prepared using the tridentate $\mathrm{SON}$ symmetrical Schiff base 2-(2-hydroxy-3-methoxybenzylidene) hydrazine carbothioamide derivatives and employing different manganese(II), copper(II) and zinc(II) starting chloride salts. These complexes were thoroughly characterized by elemental analysis, ES mass spectrometry, infrared and ${ }^{1} \mathrm{H}$ NMR spectroscopies, magnetic susceptibility measurements and molar conductivities. Electronic and magnetic susceptibility studies were also performed. All complexes obtained are four coordination compounds, with empirical formulae $\left[\mathrm{ML}_{1} \mathrm{Cl}\right]$ and $\left[\mathrm{ML}_{2} \mathrm{Cl}\right]$, where $\mathrm{M}=\mathrm{Mn}^{2+}, \mathrm{Cu}^{2+}$, and $\mathrm{Zn}^{2+}$.

\section{ACKNOWLEDGEMENT}

Taif University Researches Supporting Project number (TURSP-2020/07), Taif University, Taif, Saudi Arabia.

\section{REFERENCES}

1. Wang, D.; Lippard, S.J. Cellular processing of platinum anticancer drugs. Nat. Rev. Drug Discov. 2005, 4, 307-320.

2. Ho, J.W. Potential and cytotoxicity of cis-platinum complex with anti-tumor activity in combination therapy. Recent Pat Anticancer Drug Discov. 2006, 1, 129-134.

3. Diez, M.; Arroyo, M.; Cerdan, F.J.; Munoz, M.; Martin, M.A.; Balibrea, J.L. Serum and tissue trace metal levels in lung cancer. Oncology 1989, 46, 230-234.

4. Geraki, K.; Farquharson, M.J.; Bradley, D.A. Concentrations of $\mathrm{Fe}, \mathrm{Cu}$ and $\mathrm{Zn}$ in breast tissue: A synchrotron XRF study. Phys. Med. Biol. 2002, 47, 2327.

5. Yoshida, D.; Ikeda, Y.; Nakazawa, S. Quantitative analysis of copper, zinc and copper/zinc ratio in selected human brain tumors. J. Neuro-Oncol. 1993, 16, 109-115.

6. Mauro, C.; Matteo, T.; Jennifer, B.; Cristina, M.; Giorgio, P.; Marika, S.; Dominga, R.; Valentina, G. In vitro and in vivo anticancer activity of tridentate thiosemicarbazone copper complexes: Unravelling an unexplored pharmacological target. Eur. J. Med. Chem. 2020, 194, 112266.

7. Volynets, G.P.; Tukalo, M.A.; Bdzhola, V.G.; Derkach Nataliia M.; Gumeniuk, M.I.; Tarnavskiy, S.S.; Starosyla, S.A.; Yarmoluk, S.M., Benzaldehyde thiosemicarbazone derivatives against replicating and nonreplicating Mycobacterium tuberculosis. J. Antibiot. 2019, 72, 218-224. 
8. Prinessa, C.; Tameryn, S.; Ajit, S.; Aaron, T.; Christina, C.; Luisa, W.; Smith, G.S.; Land, K.M. Antiprotozoal activity of palladium(II) salicylaldiminato thiosemicarbazone complexes on metronidazole resistant Trichomonas vaginalis. Inorg. Chem. Commun. 2019, $102,1-4$.

9. Gatti, A.; Habtemariam, A.; Romero-Canelon, I.; Song, J.-I.; Heer, B.; Clarkson, G.J.; Dominga, R.; Sadler, P.J.; Mauro, C. Half-sandwich arene ruthenium(II) and osmium(II) thiosemicarbazone complexes: Solution behavior and antiproliferative activity. Organometallics 2018, 37, 891-899.

10. Shanmugapriya, A.; Jain, R.; Sabarinathan, D.; Kalaiarasi, G.; Dallemer, F.; Prabhakaran, R. Structurally different mono-, bi- and trinuclear Pd(II) complexes and their DNA/protein interaction, DNA cleavage, and anti-oxidant, anti-microbial and cytotoxic studies. New J. Chem. 2017, 41, 10324-10338.

11. El-Gammal O.A., Saad D.A., Al-Hossainy A.F. Synthesis, spectral characterization, optical properties and X-ray structural studies of $\mathrm{S}$ centrosymmetric $\mathrm{N}_{2} \mathrm{~S}_{2}$ or $\mathrm{N}_{2} \mathrm{~S}_{2} \mathrm{O}_{2}$ donor Schiff base ligand and its binuclear transition metal complexes. J. Mol. Struct., 2021, 1244, 130974.

12. Abd El-Wahab, H.; Abd El-Fattah, M.; El-alfy, H.M.Z.; Owda, M.E.; Lin, L.; Hamdy, I. Synthesis and characterisation of sulphonamide (Schiff base) ligand and its copper metal complex and their efficiency in polyurethane varnish as flame retardant and antimicrobial surface coating additives. Prog. Org. Coat. 2020, 142, 105577.

13. Aggoun, D.; Morallon, E.; Messasma, Z.; Ouennoughi, Y.; Bouzerafa, B.; Ourari, A.; Berenguer, R. Synthesis, characterization and DFT investigation of new metal complexes of $\mathrm{Ni}(\mathrm{II}), \mathrm{Mn}(\mathrm{II})$ and $\mathrm{VO}(\mathrm{IV})$ containing N,O-donor Schiff base ligand. J. Mol. Struct. 2021, $1231,129923$.

14. Dhanaraj, C.J.; Jebapriya, M. Metal Schiff base complexes of tridentate antipyrine based ligand: Synthesis, spectral characterisation, image analysis and biological studies. J. Mol. Struct. 2020, 1220, 128596.

15. Saleem, S.S.; Sankarganesh, M.; Jose, P.A.; Raja, J.D. Design, synthesis, antioxidant, antimicrobial, DNA binding and molecular docking studies of morpholine based Schiff base ligand and its metal(II) complexes. Inorg. Chem. Comm. 2021, 124, 108396.

16. Emayavaramban, M.; Kumar, K.; Mani, P.; Prabhakaran, B.; Muthuvel, A. Synthesis, complexation, spectral and antimicrobial study of some novel 5bromofluorobenzaldehydeoxime and semicarbazone under ultrasonic irradiation. Int. J. Adv. Chem. 2014, 2, 20-23.

17. Khan, S.A.; Asiri, A.M.; Al-Amry, K.; Malik, M.A. Synthesis, characterization, electrochemical studies, and in vitro antibacterial activity of novel thiosemicarbazone and its $\mathrm{Cu}(\mathrm{II}), \mathrm{Ni}(\mathrm{II})$, and Co(II) Complexes. Sci. World J. 2014, 2014, 592375.

18. AliAhmed, M.F.; Yunus, V.M. Microwave synthesis and antimicrobial activity of some $\mathrm{Cu}(\mathrm{II}), \mathrm{Co}(\mathrm{II}), \mathrm{Ni}(\mathrm{II})$ and $\mathrm{Cr}(\mathrm{III})$ complexes with Schiff base 2,6-pyridinedi carboxaldehyde Thiosemicabazone. Orient. J. Chem. 2014, 30, 111-117.

19. Kumari, G.; Kumar, D.; Singh, C.P.; Kumar, A.; Rana, V.B. Synthesis, characterization and antimicrobial activity of trivalent metal Schiff base complexes. J. Serb. Chem. Soc. 2010, 75, 629-663.

20. Shariar, S.M.S.; Jesmin, M.; Ali, M.M. Antibacterial activities of some Schiff bases involving thiosemicarbazide and ketones. Int. Lett. Chem. Phys. Astron. 2014, 7, 53-61.

21. Nasrin, D.; Ashraful Alam, M.; Hossain, M.N.; Nazimuddin, M. Synthesis, characterization, and antimicrobial activity of Schiff Base metal complexes derived from Sbenzyldithiocarbazate with 2-hydroxyacetophenone. Chem. J. 2013, 3, 13-19.

22. Pahontu, E.; Julea, F.; Rosu, T.; Purcarea, V. Antibacterial, antifungal, and in vitro antileukaemia activity of metal complexes with thiosemicarbazones. J. Cell Mol. Med. 2015, 19, 865-878. 
23. Pandeya, S.N.; Sriram, D.; Nath, G.; DeClercq, E. Synthesis antibacterial antifungal and anti-HIV activities of Schiff and Mannich bases derived from isatin derivatives and $N$-[4-(4'chlorophenyl)thiazol-2-yl]thiosemicarbazide. Eur. J. Pharm. Sci. 1999, 9, 25-31.

24. Yidliz, M.; Dulger, B.; Yancu, S.Y.K.; Yanpici, B.M. Synthesis and antimicrobial activity of bis (imido) Schiff bases derived from thiosemicarbazide with some 2-hydroxyaldehydes and metal complexes. J. Ind. Chem. Soc. 2004, 81, 7-12.

25. Prasad, S.; Agarwal, R.K. Cobalt(II) complexes of various thiosemicarbazones of 4aminoantipyrine: Synthesis spectral thermal and antimicrobial studies. Transit. Met. Chem. 2007, 33, 143-149.

26. Parekh, A.K.; Desai, K.K. Synthesis, and antibacterial activity of thiosemicarbazones. Indian J. Chem. 2006, 45, 1072.

27. Murthy, N.; Dharmarajan, T.S. Synthesis, characterization, and biological activity of copper(II) complexes with phenylglyoxal bis-(thiosemicarbazones). Asian J. Chem. 2006, $14,1325-1330$

28. Ferrari, M.B.; Capacchi, S.; Reffo, G.; Aelosi, G. Synthesis, structural characterization and biological activity of $p$-fluorobenzaldehyde thiosemicarbazones and of a nickel complexes. J. Inorg. Biochem. 2000, 81, 89-97.

29. Płowaś, I.; Świergiel, J.; Jadżyn, J. Electrical conductivity in dimethyl sulfoxide + potassium iodide solutions at different concentrations and temperatures. J. Chem. Eng. Data 2014, 59, 2360-2366.

30. Lever, A.B.P.; Mantovani, E. Far-infrared and electronic spectra of some bis(ethylenediamine) and related complexes of copper(II) and the relevance of these data to tetragonal distortion and bond strengths. Inorg. Chem. 1971, 10, 817-826.

31. Munde, A.S.; Shelke, V.A.; Jadhav, S.M.; Kirdant, A.S.; Chondhekar, T.K. Synthesis, characterization and antimicrobial activities of some transition metal complexes of biologically active asymmetrical tetradentate ligands. Adv. Appl. Sci. Res. 2012, 3, 175-182.

32. Cotton, F.A.; Wilkinson, G.; Murillo, C.A.; Bochmann, M. Advanced Inorganic Chemistry, 6th ed., Wiley: New York; 1999.

33. NithaL, P.; Aswathy, R.; Mathews, N.E.; Kumari, B.S.; Mohanan, K. Synthesis, spectroscopic characterisation, DNA cleavage, superoxidase dismutase activity and antibacterial properties of some transition metal complexes of a novel bidentate Schiff base derived from isatin and 2-aminopyrimidine. Spectrochim. Acta A Mol. Biomol. Spectrosc. 2014, 118, 154-161.

34. Singh, N.K.; Singh, S.B. Complexes of 1-isonicotinoyl-4-benzoyl-3-thiosemicarbazide with manganese(II), iron(III), chromium(III), cobalt(II), nickel(II), copper(II) and zinc(II). Transit. Met. Chem. 2001, 26, 487-495.

35. Chandra, S.; Kumar, U. Spectral studies of coordination compounds of cobalt(II) with thiosemicarbazone of heterocyclic ketone. Spectrochim. Acta A 2005, 62, 940-944.

36. Youssef, N.S.; Hegab, K.H. Synthesis and characterization of some transition metal complexes of thiosemicarbazones derived from 2-acetylpyrrole and 2-acetylfuran. Synth. React. Inorg. Met. Org. Chem. 2005, 35, 391-399. 